\title{
Concomitant Expression of Endothelin Receptor Subtype and Isopeptide by Pheochromocytoma and Bovine Adrenal Medulla
}

\author{
Yukio Hirata, Taihei Imai, Satoru Eguchi, and Fumiaki Marumo
}

\begin{abstract}
Endothelin (ET) isopeptide and receptor subtype are distributed in various tissues, suggesting diverse functions as local factors other than acting as potent vasoconstrictors. We have studied whether ET isopeptide and receptor subtype are concomitantly expressed in pheochromocytoma and bovine adrenal medulla by binding studies and Northern blot analysis and compared the results with those in human and bovine adrenal cortex. Binding studies using [ $\left.{ }^{125} \mathrm{I}\right] \mathrm{ET}-1$ as a radioligand revealed a single class of high-affinity binding sites for ET-1 in membranes from two pheochromocytomas and normal bovine adrenal medulla, which were almost comparable to those from human and bovine adrenal cortex. ET-1 and ET-2 equipotently and competitively inhibited [ $\left.{ }^{125} I\right]$ ET-1 binding to the membranes, whereas ET-3 was far less potent than ET-1 at higher concentrations, suggesting heterogeneous subpopulations of ET receptors. Northern blot analysis using cDNAs for $\mathbf{E T}_{\mathrm{A}}$ and $E T_{B}$ receptors revealed that both $\mathrm{ET}_{\mathrm{A}}$ and ET $_{в}$ receptor mRNAs are expressed in pheochromocytoma and bovine adrenal medulla in a similar fashion as in human and bovine adrenal cortex. Northern blot analysis using cDNAs for human preproET-1 and preproET-3 as probes also revealed the concomitant expression of preproET-1 mRNA in pheochromocytoma and bovine adrenal medulla and preproET-3 mRNA in human adrenal cortex. These data demonstrate for the first time that ET receptor subtype $\left(\right.$ ET $_{A}$ and ET ET ) and ET isopeptide (ET-1 and ET-3) are concomitantly expressed by pheochromocytoma as well as bovine adrenal medulla, suggesting the paracrine/autocrine function of ET in adrenomedullary chromaffin cells. (Hypertens Res 1993;16: 215-219)
\end{abstract}

Key Words: endothelin, receptor subtype, isopeptide, pheochromocytoma, adrenal medulla

Endothelin (ET) is a potent vasoconstrictor peptide with a 21-amino-acid residue, originally isolated from porcine endothelial cells (I). Subsequent cDNA cloning from human genomic library revealed the existence of three distinct isopeptides, termed ET-1, ET-2 and ET-3 (2). These three isopeptide mRNAs have been shown to be distributed in a variety of tissues of human and other species. Recently, at least two similar, but distinct $\mathrm{ET}$ receptors, designated $\mathrm{ET}_{\mathrm{A}}$ and $\mathrm{ET}_{\mathrm{B}}$ subtype, have been cloned and sequenced $(3,4)$; ET $\mathrm{E}_{\mathrm{A}}$ receptor is selective for ET-1 and ET-2, while ETв receptor is non-isopeptide-selective. These two receptor subtypes have also been shown to be distributed in various tissues where the three isopeptides are colocalized. These observations led to the suggestion that ET isopeptides may function as an autocrine/ paracrine factor in various tissues.

It has been reported that ET-1 stimulates hormone secretion from various endocrine glands, including atrial natriuretic peptide from rat cardiocytes (5), gonadotropins from rat pituitary gland
(6), vasopressin from rat hypothalamus (7), aldosterone from adrenal zona glomerulosa cells (8), and catecholamines from bovine adrenomedullary chromaffin cells (9). However, there is currently no evidence available demonstrating whether or not ET isopeptide and its receptor subtype are concomitantly present in human and bovine adrenal medulla. Therefore, the present investigation using binding study and Northern blot analysis was designed to elucidate whether ET isopeptide and its receptor subtype are concomitantly expressed by pheochromocytoma and bovine adrenal medulla and to compare the results with those in human and bovine adrenal cortex.

\section{Methods}

Patients

Case 1: A 32-year-old male was found to have a right adrenal incidentaloma $(2.2 \times 2.3 \times 2.0 \mathrm{~cm})$ by CT scan and magnetic resonance imaging. He had been normotensive $(120 / 60 \mathrm{mmHg})$ without any epi-

From the Endocrine-Hypertension Division, Second Department of Internal Medicine, Tokyo Medical and Dental University, Tokyo, Japan.

Address for Reprints: Yukio Hirata, M.D., Endocrine-Hypertension Division, Second Department of Medicine, Tokyo Medical and Dental University, Yushima 1-5-45, Bunkyo-ku, Tokyo 113, Japan.

Received April 26, 1993; accepted in revised form July 6, 1993. 
sodes of paroxysmal hypertension. 24-h urinary excretions of vanyl mandelic acid, norepinephrine, epinephrine and dopamine were $6.2 \mathrm{mg}, 206 \mu \mathrm{g}, 14$ $\mu \mathrm{g}$ and $919 \mu \mathrm{g}$, respectively.

Case 2: A 47-year-old male with a paroxysmal hypertensive attack $(200 / 100 \mathrm{mmHg})$ was found to have a left adrenal mass $(3.7 \times 2.5 \times 3.5 \mathrm{~cm})$ by $\mathrm{CT}$ scan and magnetic resonance imaging. 24-h urinary excretions of vanyl mandelic acid, norepinephrine, epinephrine and dopamine were $16.4 \mathrm{mg}, 2036 \mu \mathrm{g}$, $119 \mu \mathrm{g}$ and $1943 \mu \mathrm{g}$, respectively.

Both cases underwent surgical removal of the adrenal tumors. Pathologically the tumor specimens from both cases were compatible with the diagnosis of pheochromocytoma. Their operative and postoperative courses were uneventful.

\section{Tissue Samples}

Tumor tissues from the two cases with pheochromocytoma were obtained during surgery. Adjacent normal cortical tissue was separated from the tumor tissue of Case 2. Bovine adrenal glands obtained at a local slaughterhouse were dissected into cortical and medullary portions. Tissue samples were immediately frozen in liquid nitrogen and stored at $-80^{\circ} \mathrm{C}$ until analysis.

\section{Binding Study}

Adrenal tissue specimens were homogenized by a Polytron homogenizer in $20 \mathrm{mM}$ phosphate buffer, pH 7.5, $(130 \mathrm{mM} \mathrm{NaCl}, 1 \mathrm{mM}$ ethylenediaminetetraacetic acid, $0.2 \mathrm{mM}$ phenylmethylsufonyl fluoride, $10 \mu \mathrm{g} / \mathrm{ml}$ pepstatin, $10 \mu \mathrm{g} / \mathrm{ml}$ leupeptin), and centrifuged at $15,000 \times g$ for $5 \mathrm{~min}$. The pellets were resuspended in the same buffer and used as membrane preparations. For binding studies, membrane suspensions (10-50 $\mu \mathrm{g}$ protein) were incubated with $25 \mathrm{pM}\left[{ }^{125} \mathrm{I}\right] \mathrm{ET}-1$ (Amersham Japan, Tokyo) in the absence and the presence of various concentrations of unlabeled ET-1, ET-2 and ET-3 (Peptide Institute Inc., Osaka) at $30^{\circ} \mathrm{C}$ for $30 \mathrm{~min}$ in the same manner as recently reported (10). Incubation was terminated by the removal of free radioactive ligands after centrifugation. Specific binding was determined by subtracting nonspecific binding in the presence of excess $\left(10^{-7} \mathrm{M}\right)$ unlabeled ET-1 from total binding.

\section{Northern Blot Analysis}

RNA was prepared by the acid guanidinium thiocyanate-phenol-chloroform (AGPC) method (11). Briefly, frozen tissue specimens from Case 2 and bovine adrenal glands were homogenized in guanidinium solution $(10 \mathrm{ml} / \mathrm{g}$ tissue: $4 \mathrm{M}$ guanidinium thiocyanate, $25 \mathrm{mM}$ sodium citrate, $0.5 \%$ sarcosyl, 1\% 2-mercaptoethanol) using a Polytron homogenizer. One $\mathrm{ml} 2 \mathrm{M}$ sodium acetate $(\mathrm{pH} 4.0)$, $10 \mathrm{ml}$ water-saturated phenol, and $2 \mathrm{ml}$ chloroformisoamyl alcohol mixture $(49: 1)$ were added to the homogenates with thorough mixing and vortexing, and the mixture was cooled on ice for $15 \mathrm{~min}$. After centrifugation at $10,000 \times \mathrm{g}$ for $20 \mathrm{~min}$ at $4^{\circ} \mathrm{C}$, an aqueous phase containing RNA was precipitated twice with $10 \mathrm{ml}$ isopropyl alcohol at $-20^{\circ} \mathrm{C}$ for
20 min. Total RNA was pelleted by centrifugation, washed with $70 \%$ ethanol, dissolved in diethylpyrocarbonate-treated water, and subjected to poly $(\mathrm{A})^{+}$selection by oligo(dT) chromatography. Poly $(\mathrm{A})^{+}$RNA $(10 \mu \mathrm{g})$ was separated by formaldehyde $1.1 \%$ agarose gel electrophoresis and transferred to a MagnaGraph nylon membrane (Micron Separations Inc., Westborough, MA). RNA immobilized on the membrane was hybridized respectively with cloned cDNAs for human and bovine $E T_{A}$ and $E T_{B}$ receptors and those for preproET-1 and preproET-3 as probes, in the presence of $50 \%$ formamide at $42^{\circ} \mathrm{C}$ over $16 \mathrm{~h}$. The cDNA inserts of human $\mathrm{ET}_{\mathrm{A}}$ and $\mathrm{ET}_{\mathrm{B}}$ receptor (12), bovine $\mathrm{ET}_{\mathrm{A}}$ receptor (3) and $\mathrm{ET}_{\mathrm{B}}$ receptor (13), human preproET1 and preproET-3 (10), and bovine preproET-1 (14) were labeled with deoxycytidine $5^{\prime}-\left[{ }^{32} \mathrm{P}\right]$ triphosphate (111 TBq/mmol, DuPont NEN Research Products, Boston, MA) by the random-primed labeling method. The membranes were washed finally in 0.1 $\times$ SSPE $\left(15 \mathrm{mM} \mathrm{NaCl}, 1 \mathrm{mM} \mathrm{NaH} \mathrm{PO}_{4}, 0.1 \mathrm{mM}\right.$ ethylenediaminetetraacetic acid) / $0.5 \%$ sodium dodecyl sulfate at $50^{\circ} \mathrm{C}$, and autoradiographed with intensifying screens at $-80^{\circ} \mathrm{C}$ for $20-24 \mathrm{~h}$.

\section{Results}

Equilibrium binding of $\left[{ }^{125} \mathrm{I}\right] \mathrm{ET}-1$ to the membrane preparations from human and bovine adrenal glands was reached after $30 \mathrm{~min}$ at $30^{\circ} \mathrm{C}$; non-specific binding was less than $10 \%$ of total binding.

Competitive bindings of $\left[{ }^{125} I\right] E T-1$ to the membranes from two pheochromocytomas (Cases 1 and 2) by unlabeled isopeptides are shown in Fig. 1. ET-1 competitively inhibited the binding of [ ${ }^{125}$ I]ET-1 to the membranes in both cases. Scatchard analysis (Inset) revealed the presence of a single class of high-affinity binding sites for ET-1; the apparent dissociation constants $\left(K_{\mathrm{d}}\right)$ were $3.7 \times 10^{-11} \mathrm{M}$ (Case 1) and $3.5 \times 10^{-10} \mathrm{M}$ (Case 2), and the maximal binding capacities $\left(B_{\max }\right)$ were $130 \mathrm{fmol} / \mathrm{mg}$ protein (Case 1) and $145 \mathrm{fmol} / \mathrm{mg}$ protein (Case 2), respectively. ET-2 was about 5-fold less potent than ET-1 to displace $\left[{ }^{125} \mathrm{I}\right] \mathrm{ET}-1$ from its binding sites, whereas ET-3 was far less potent than ET-1 and ET-2 with the apparent inhibition constants $\left(K_{\mathrm{i}}\right)$ of $2.2 \times 10^{-8}$ $\mathrm{M}$ (Case 1) and $4.5 \times 10^{-8} \mathrm{M}$ (Case 2), respectively.

Competitive binding studies using membranes of normal bovine adrenal cortex and medulla are shown in Fig. 2. ET-1 competitively inhibited the binding of $\left[{ }^{125} \mathrm{I}\right] \mathrm{ET}-1$ to the membranes from bovine adrenal cortex and medulla; the apparent $K_{\mathrm{d}} \mathrm{S}$ in bovine adrenal cortex and medulla were $3.5 \times$ $10^{-11} \mathrm{M}$ and $4.5 \times 10^{-11} \mathrm{M}$, respectively, and $B_{\max } \mathrm{s}$ were $69 \mathrm{fmol} / \mathrm{mg}$ and $55 \mathrm{fmol} / \mathrm{mg}$, respectively. ET2 was almost as potent as ET-1 in adrenal cortex and about four-fold less potent than ET-1 in adrenal medulla, whereas ET-3 was far less potent than ET-1 to displace [ ${ }^{125}$ I]ET-1 from its binding sites in both adrenal cortex and medulla at higher concentrations $\left(10^{-9}-10^{-7} \mathrm{M}\right)$. The same binding characteristics were noted in the membrane from human adrenal cortex from Case 2 (data not shown).

Northern blot analysis using cDNAs for human 


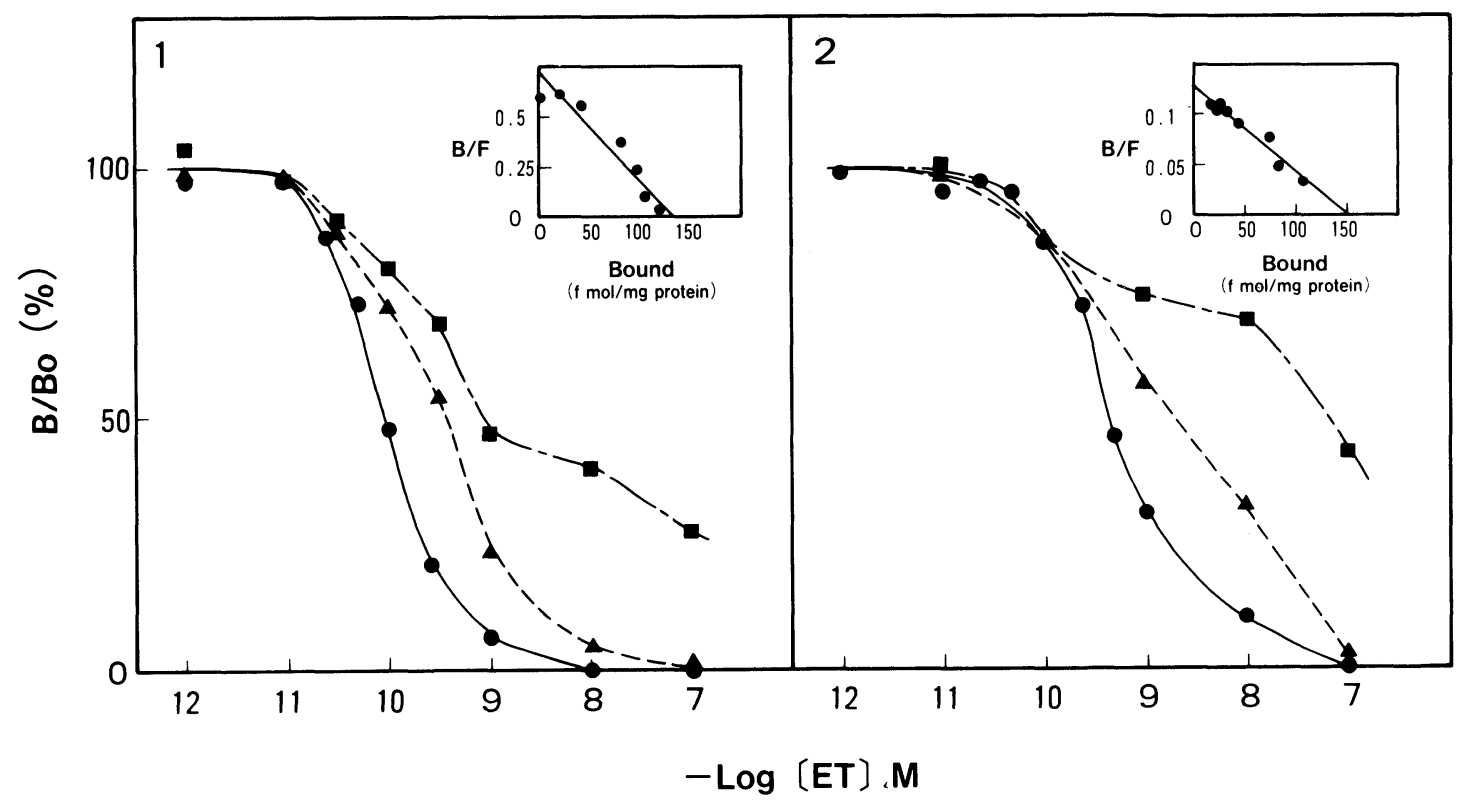

Fig. 1. Competitive binding of $\left.{ }^{125} I\right] E T-1$ by ET isopeptide to pheochromocytomas. Membranes from two pheochromocytomas (Cases 1 and 2) were incubated with ${ }^{125}$ I]ET-1 at $30^{\circ} \mathrm{C}$ for 30 min in the absence and presence of unlabeled ET-1

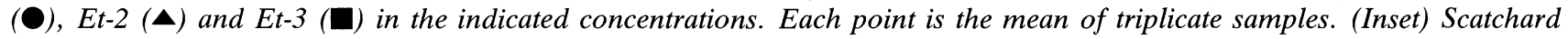
plots of ET-1 binding.

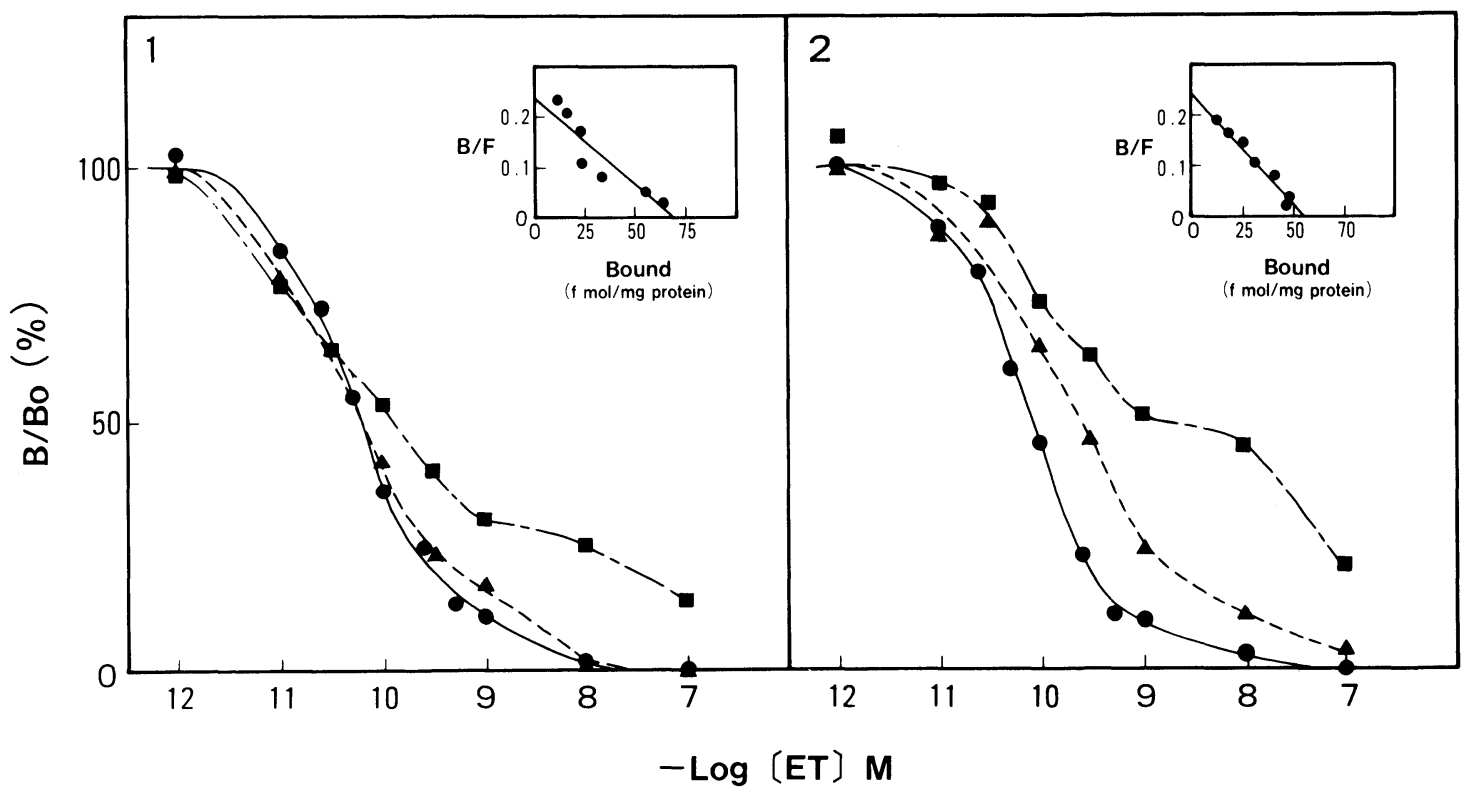

Fig. 2. Competitive binding of [125I]ET-1 by ET isopeptide to bovine adrenal cortex and medulla. Membranes from bovine adrenal cortex (1) and medulla (2) were incubated with $\left[^{125} I\right] E T-1$ at $37^{\circ} \mathrm{C}$ for 30 min in the absence and presence of unlabeled ET-1 (O), ET-2 (A) and ET-3 (ם) in the indicated concentrations. Data are plotted as in Fig. 1.

$\mathrm{ET}_{\mathrm{A}}$ and $\mathrm{ET}_{\mathrm{B}}$ receptors and human preproET-1 and preproET-3 as probes in pheochromocytoma and adrenal cortex from Case 2 is shown in Fig. 3. Two distinct bands $(4.3 \mathrm{~kb}$ and $4.8 \mathrm{~kb})$ corresponding to the sizes of human $\mathrm{ET}_{\mathrm{A}}$ and $\mathrm{ET}_{\mathrm{B}}$ mRNA were observed in both pheochromocytoma and adrenal cortex. Two distinct bands $(2.3 \mathrm{~kb}$ and $2.8 \mathrm{~kb})$ corresponding to the sizes of human preproET-1 and preproET-3 mRNA were noted in pheochromocyto- ma and adrenal cortex; preproET-1 mRNA was evident in pheochromocytoma, whereas preproET-3 mRNA was predominant in adrenal cortex.

Northern blot analysis using cDNAs for bovine preproET-1 as probes in bovine adrenal cortex and medulla is shown in Fig. 4. Two bands $(4.3 \mathrm{~kb}$ and $3.3 \mathrm{~kb}$ ) corresponding to the sizes of bovine $\mathrm{ET}_{\mathrm{A}}$ mRNA and a single band $(4.8 \mathrm{~kb})$ corresponding to the size of bovine $\mathrm{ET}_{\mathbf{B}}$ mRNA were observed in 


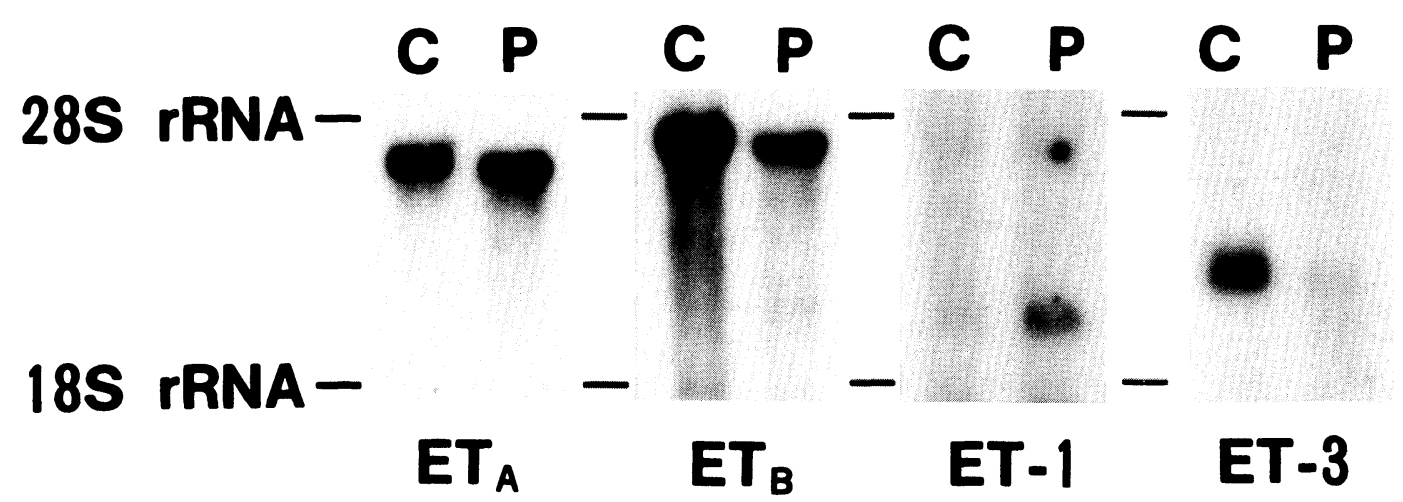

Fig. 3. Northern blot analysis of human ET receptor subtype and isopeptide in pheochromocytoma and adrenal cortex. Poly $(A)^{+}$RNA $(10 \mu \mathrm{g})$ from pheochromocytoma $(P)$ and adjacent adrenal cortex $(C)$ from Case 2 was subjected to Northern blot using $\left.{ }^{32} P\right] c D N A$ s for human $E T_{A}$ and ET, preproET-1 and preproET-3 as probes, respectively. Arrows show $28 S$ and $18 S$ ribosomal $R N A$.

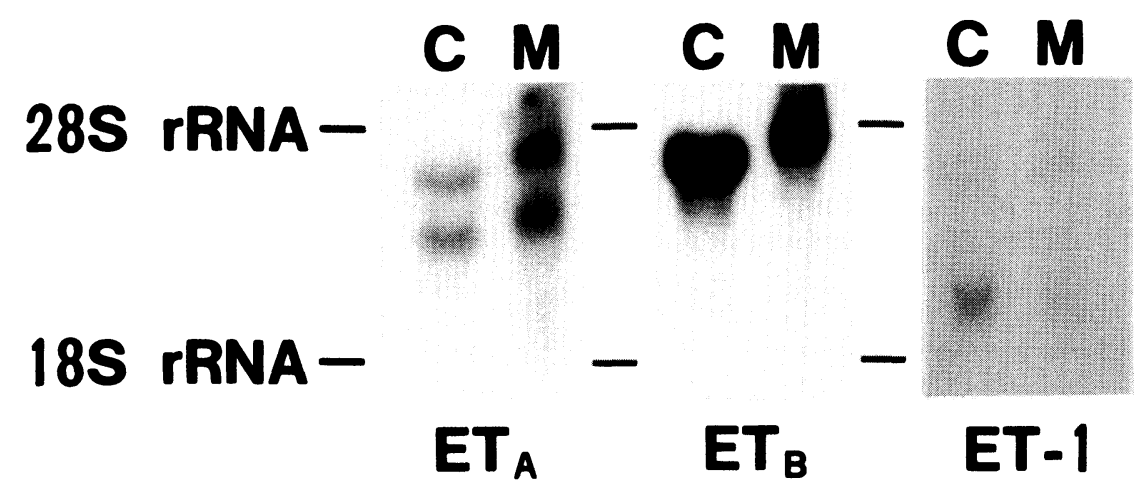

Fig. 4. Northern blot analysis of bovine ET receptor subtype and preproET-1 in bovine adrenal cortex and medulla. Poly $(A)^{+}$RNA $(10 \mu \mathrm{g})$ from normal bovine adrenal cortex $(C)$ and medulla $(M)$ was subjected to Northern blot using $\left.{ }^{32} P\right] c D N A s$ for bovine $E T_{A}, E T_{B}$ and preproET-1 as probes, respectively.

both adrenal cortex and medulla. A single band $(2.3 \mathrm{~kb})$ corresponding to the size of bovine preproET-1 mRNA was distinctly noted in cortical tissue, but only faintly in medullary tissue.

\section{Discussion}

It has been shown that ET-1 stimulates release of aldosterone from rat adrenal zona glomerulosa cells (8) and catecholamines from bovine adrenomedullary chromaffin cells (9), suggesting that it acts as a local regulator of hormone secretion in adrenal glands. Recently, Wilkes and Broader (15) have reported that cultured bovine adrenomedullary chromaffin cells possess non-isopeptide-selective ET receptor, possibly ETв subtype, as assessed by binding studies. The present competitive binding studies clearly demonstrated that two pheochromocytomas, human adrenal tumors derived from adrenomedullary chromaffin cells, possessed a single class of binding sites for ET-1 with high affinities $\left(K_{\mathrm{d}}\right.$ : $\left.10^{-11}-10^{-10} \mathrm{M}\right)$ and capacities $\left(B_{\max }: 130-145\right.$ $\mathrm{fmol} / \mathrm{mg}$ protein), almost comparable to those of normal bovine adrenal medulla. In the present binding studies, however, ET-3 produced biphasic competition binding curves against $\left[{ }^{125} \mathrm{I}\right] \mathrm{ET}-1$ in the membranes from pheochromocytomas and bovine adrenal medulla. These data are consistent with the existence of heterogenous populations of ET receptors in these adrenal tissues. Northern blot analysis using cDNAs for human $\mathrm{ET}_{\mathrm{A}}$ and $\mathrm{ET}_{\mathrm{B}}$ receptors as probes revealed concomitant expression of $\mathrm{ET}_{\mathrm{A}}$ and $\mathrm{ET}_{\mathrm{B}}$ receptor mRNAs in pheochromocytoma and bovine adrenal medulla, thus verifying the existence of two distinct ET receptor subtypes in adrenomedullary tissues. The co-expression of $\mathrm{ET}_{\mathrm{A}}$ and $\mathrm{ET}_{\mathrm{B}}$ receptor mRNAs by human as well as bovine adrencortical tissues as demonstrated in this study is consistent with our previous observations (10). The reason why Wilkens and Boarder (15) could not demonstrate the presence of $\mathrm{ET}_{\mathrm{A}}$ receptors in bovine adrenal chromaffin cells remains unknown. Possibly, digestion of adrenomedullary chromaffin cells by collagenase/protease and/or the culture conditions employed in their study may have led to preferential loss of $\mathrm{ET}_{\mathrm{A}}$ receptor.

The present Northern blot analysis using cDNAs for human preproET-1 and preproET-3 as probes further demonstrated the expression of both preproET-1 and preproET-3 mRNA in human adrenal tissues; preproET-1 mRNA and preproET-3 mRNA were predominant in pheochromocytoma 
and in the adjacent adrenocortical tissue, respectively. This is in contrast to the predominant expression of preproET- 1 mRNA in bovine adrenal cortex as demonstrated by Northern blot analysis. Species differences and/or malignant transformation of adrenal chromaffin cells may partly account for the different expression of ET isopeptide. Our data confirm our previous observation that ET isopeptide and receptor subtype are concomitantly expressed by human adrenocortical tissues and adenomas (10), and further extend the concomitant expression of ET isopeptide and receptor subtype by adrenal medulla and pheochromocytoma.

The physiological function of ET isopeptide in adrenal medulla remains obscure. ET-1 has mitogenic action on a number of cells, including vascular smooth muscle cells (16), glomerular mesangial cells (17), and certain human tumor cells (18). Therefore, it is possible to speculate that ET-1, in addition to its stimulatory effect on catecholamine secretion (15), may affect growth and/or differentiation of adrenal chromaffin cells as an autocrine/paracrine factor. The pathophysiological significance of the ET family in relation to tumor growth of pheochromocytoma thus needs to be determined.

\section{Acknowledgments}

We thank Dr. T. Masaki (Kyoto University) for cDNAs of human $\mathrm{ET}_{\mathrm{A}}$ and $\mathrm{ET}_{\mathrm{B}}$ receptor and human preproET-1 and preproET-3, Dr. S. Nakanishi (Kyoto University) for bovine $\mathrm{ET}_{\mathrm{A}}$ receptor, and Dr. S. Hirose (Tokyo Institute of Technology) for bovine ETв receptor, used as probes in this study. This study was supported in part by Grantsin-Aid from the Ministry of Education, Science and Culture, and the Ministry of Health and Welfare, of Japan and a fund from the Uehara Memorial Foundation.

\section{References}

1. Yanagisawa $\mathbf{M}$, Kurihara H, Kimura S, et al: A novel potent vasoconstrictor produced by vascular endothelial cells. Nature 1988; 332: 411-415.

2. Inoue $\mathrm{A}$, Yanagisawa $\mathrm{M}$, Kimura $\mathrm{S}$, et al: The human endothelin family: three structurally and pharmacologically distinct isopeptides predicted by three separate genes. Proc Natl Acad Sci USA 1989; 86: 2863-2867.

3. Arai H, Hori S, Aramori I, Ohkubo H, Nakanishi S: Cloning and expression of a cDNA encoding an endothelin receptor. Nature 1990; 348: 730-732.

4. Sakurai $\mathrm{T}$, Yanagisawa $\mathrm{M}$, Takuwa $\mathrm{H}$, et al: Cloning of a cDNA encoding a non-isopeptide-selective subtype of the endothelin receptor. Nature 1990; 348:
732-735.

5. Fukuda Y, Hirata Y, Yoshimi $\mathrm{H}$, et al: Endothelin is a potent secretagogue for atrial natriuretic peptide in cultured rat atrial myocytes. Biochem Biophys Res Commun 1988; 155: 167-172.

6. Stojilkovic SS, Merelli F, Iida T, Krsmanovic LZ, Catt KJ: Endothelin stimulation of cytosolic calcium and gonadotropin secretion in anterior pituitary cells. Science 1990; 248: 1663-1666.

7. Shichiri M, Hirata Y, Kanno K, Ohta K, Emori T, Marumo F: Effect of endothelin-1 on release of arginine-vasopressin from perifused rat hypothalamus. Biochem Biophys Res Commun 1989; 163: 1332-1337.

8. Cozza EN, Gomez-Sanchez CE, Foecking MF, Chiou S: Endothelin binding to cultured calf adrenal zona glomerulosa cells and stimulation of aldosterone secretion. J Clin Invest 1989; 84: 1032-1035.

9. Boarder MR, Marriott DB: Endothelin-1 stimulation of noradrenaline and adrenaline release from adrenal chromaffin cells. Biochem Pharmacol 1991; 41:521-526.

10. Imai $\mathrm{T}$, Hirata $\mathrm{Y}$, Eguchi $\mathrm{S}$, et al: Concomitant expression of receptor subtype and isopeptide of endothelin by human adrenal gland. Biochem Biophys Res Commun 1992; 182: 1115-1121.

11. Chomczynski P, Sacchi N: Single-step method of RNA isolation by acid guanidinium thiocyanatephenol-chloroform extraction. Anal Biochem 1987; 162: $156-159$

12. Sakamoto A, Yanagisawa M, Sakurai T, Takuma Y, Yanagisawa $\mathrm{H}$, Masaki $\mathrm{T}$ : Cloning and functional expression of human cDNA for the $\mathrm{ET}_{\mathrm{B}}$ endothelin receptor. Biochem Biophys Res Commun 1991; 178: 656-663.

13. Saito $\mathrm{Y}$, Mizuno $\mathrm{T}$, Itakura $\mathrm{M}$, et al: $\mathrm{ET}_{\mathrm{B}}$ receptor and identification of signal peptidase and metal proteinase cleavage sites. J Biol Chem 1991; 266: 23433-23437.

14. Imai T, Hirata $\mathrm{Y}$, Emori $\mathrm{T}$, Yanagisawa M, Masaki $\mathrm{T}$, Marumo $\mathrm{F}$ : Induction of endothelin-1 gene by angiotensin and vasopressin in endothelial cells. Hypertension 1992; 19: 753-757.

15. Wilkes LC, Boarder MR: Characterization of the endothelin binding site on bovine adrenomedullary chromaffin cells: comparison with vascular smooth muscle cells. Evidence for receptor heterogeneity. $J$ Pharmacol Exp Ther 1991; 256: 628-633.

16. Hirata Y, Takagi Y, Fukuda Y, Marumo F: Endothelin is a potent mitogen for rat vascular smooth muscle cells. Atherosclerosis 1989; 78: 225-228.

17. Simonson MS, Wann S, Mene P, et al: Endothelin stimulates phosholipase $\mathrm{C}, \mathrm{Na}^{+} / \mathrm{H}^{+}$exchange, c-fos expression, and mitogenesis in rat mesangial cells. $J$ Clin Invest 1989; 83: 708-712.

18. Shichiri M, Hirata Y, Nakajima T, et al: Endothelin1 is an autocrine/paracrine growth factor for human cancer cell lines. J Clin Invest 1991; 87: 1867-1871. 